Syntax Literate : Jurnal Ilmiah Indonesia p-ISSN: 2541-0849

e-ISSN: 2548-1398

Vol. 5, No. 5 Mei 2020

\title{
IMPLEMENTASI KEBIJAKAN PENGAMANAN ASET TANAH MILIK PEMERINTAH KOTA SEMARANG BERDASARKAN PP NOMOR 27 TAHUN 2014
}

\section{Rudy Kurniawan}

Universitas Diponegoro (UNDIP) Semarang

Email: rudy.70974@gmail.com,

\section{Abstract}

Fixed assets are tangible assets that have a useful life of more than 12 months to be used in government activities or utilized by the general public. The government must record its fixed assets even though these fixed assets are used by other parties. This study aims to analyze the implementation of the policy of securing land assets belonging to the Semarang City Government and analyze the supporting and inhibiting factors in the implementation of the security policy. The research approach used is qualitative using a policy implementation model according to Edward I. The results of the study indicate that the problems faced are: Not all managers of Regional Assets / Property understand deeply Permendagri No. 17 of 2007 which became a reference in the management of assets or regional assets; Many ownership of land assets are not supported by evidence of legal land rights; Administration of ownership evidence for Regional Assets is still a lot of disorderly. The process of securing land assets is carried out by: Identifying existing Semarang City government assets; Administrative safeguards; Physical security; Legal action. Inhibiting factors: Bureaucratic system that is still less efficient and the weak coordination that occurs between related agencies; Human resource expertise possessed by the parties involved is still not optimal; The availability of facilities to support the implementation of policies has not been fully adequate; The authority given to ASN in implementing the Semarang City Government Land Assets Security Policy is still ineffective. Supporting factors: There are incentives as implementers; Good communication and coordination with related parties; Inviting the public to participate in physically securing Semarang City Government's land assets.

Keywords: Implementation, security, assets, land, government

\section{Abstrak}

Aset tetap merupakan aset berwujud yang memiliki masa guna lebih dari 12 bulan untuk dipakai dalam aktivitas pemerintah ataupun digunakan oleh masyarakat global. Pemerintah harus mencatat aset tetap yang dimilikinya walaupun aset tetap itu dipakai oleh pihak lain. Penelitian ini bertujuan menganalisis implementasi kebijakan pengamanan aset tanah milik Pemerintah Kota Semarang serta menganalisis faktor-faktor pendukung serta penghambat penerapan prosedur pengamanannya. Pendekatan penelitian yang digunakan yaitu kualitatif dengan menggunakan model implemantasi kebijakan munurut Edward I. Hasil penelitian 
menunjukkan bahwa permasalahan yang dihadapi yaitu: Tidak semua pengelola Aset/Barang Milik Daerah memahami secara mendalam Permendagri No.17 Tahun 2007 yang menjadi acuan dalam pengelolaan Aset ataupun Barang Milik Daerah; Kepemilikan aset tanah masih banyak yang tidak didukung dengan bukti hak atas tanah yang sah; Administrasi terhadap bukti kepemilikan Aset Daerah masih banyak yang tidak tertib. Proses pengamanan pada aset tanah dilakukan dengan cara: Mengidentifikasi aset pemerintah Kota Semarang yang ada; Pengamanan administratif; Pengamanan fisik; Tindakan hukum. Faktor penghambat: Sistem birokrasi yang masih kurang efisien dan masih lemahnya koordinasi yang terjadi antar instansi yang terkait; Keahlian sumberdaya manusia yang dimiliki oleh pihak-pihak yang terkait masih kurang optimal; Ketersediaan fasilitas untuk mendukung pelaksanaan kebijakan belum sepenuhnya memadai; Kewenangan yang diberikan pada ASN dalam melaksanakan Kebijakan Pengamanan Aset Tanah Milik Pemerintah Kota Semarang masih kurang efektif. Faktor pendukung : Adanya insentif sebagai pelaksana; Adanya komunikasi serta koordinasi yang cukup baik dengan pihak-pihak terkait; Mengajak masyarakat untuk berperan serta dalam mengamankan secara fisik aset tanah Milik Pemerintah Kota Semarang.

Kata kunci: Implementasi, pengamanan, aset, tanah, pemerintah

\section{Pendahuluan}

Lahirnya prinsip Good Governance, menuntut Pemerintah Daerah harus membuat laporan keuangan yang transparan dan akuntabel. Tujuan utamanya antara lain adalah agar semua Aset/Barang Milik Daerah (BMD) yang dilaporkan dapat dipertanggungjawabkan terhadap masyarakat secara menyeluruh serta sesuai dengan tujuan. Definisi Aset Tetap dalam Pernyataan Standar Akuntansi Pemerintahan (PSAP) ialah aset berwujud yang memiliki masa guna lebih dari 12 (dua belas) bulan untuk dipakai dalam aktivitas pemerintah ataupun digunakan oleh masyarakat secara luas. Dengan pembatasan definisi itu sehingga pemerintah semestinya mencatat aset tetap yang dimilikinya walaupun aset tetap itu dipakai oleh pihak lain. Pemerintahpun semestinya mencatat hak atas tanah menjadi aset tetap. Dalam PSAP 07, aset tetap di neraca dikelompokkan enam bagian, yaitu Tanah; Peralatan dan Mesin; Gedung dan Bangunan; Jalan, Irigasi, dan Jaringan; Aset Tetap Lainnya; dan Konstruksi Dalam Pengerjaan.

Pengamanan aset ialah aktivitas perilaku pengelolaan dalam pengurusan BMD dalam bentuk fisik, administrasi, serta perilaku usaha hukum. Pengamanan BMD merupakan kewajiban dari pengelola, pengguna, dan/atau kuasa pengguna barang. Kegiatan pengamanan meliputi pengamanan administratif, fisik dan hukum.

a. Pengamanan administrasi ialah aktivitas yang dilaksanakan pejabat yang dpilih untuk menatausahakan dalam kerangka mensejahterakan barang milik daerah dari segi administratif.

b. Pengamanan fisik ialah aktivitas yang dilaksanakan oleh pejabat yang dipilih untuk mengamankan barang milik daerah yang diarahkan untuk menghambat 
berlangsungnya depresiasi fungsi barang, penurunan kuantitas barang serta hilangnya barang.

c. Pengamanan hukum ialah aktivitas untuk menyimpan barang milik daerah dengan langkah menyempurnakan bukti status kepemilikan.

Berdasarkan data dari Laporan Hasil Pemeriksaan BPK Perwakilan Provinsi Jawa Tengah (LHP BPK) atas Pemeriksaan Manajemen Aset pada Pemerintah Kota Semarang TA. 2015 dan TA. 2016 (Semester I) masih terdapat beberapa catatan terkait penatausahaan aset tetap, adapun catatan tersebut yakni: Masih banyak tanah belum bersertifikat, sertipikat atas nama pihak lain, papan tanda kepemilikan tanah Pemkot Semarang tidak ada. Dalam LHP BPK Nomor 111/LHP/BPK/XVIII.SMG/10/2016 tanggal 25 Oktober 2016 mengungkap temuan terkait pengamanan aset tetap (tanah) yaitu belum sepenuhnya tanah milik Pemkot Semarang bersertifikat, dan belum sepenuhnya tanah milik Pemkot Semarang mempunyai papan nama tanda kepemilikan.

Faktor lainnya yang mempengaruhi adalah terbatasnya tenaga SDM untuk melakukan penjagaan terhadap keamanan aset tanah tersebut. Sumber daya manusia merupakan bagian penting dalam aktivitas kerja (Saridawati, 2018). Kebijakan untuk pengamanan aset belum mengakomodir semua hal yang diperlukan, seperti penguasaan dan pemeliharaan aset agar tidak hilang, rusak, atau dicuri, dan sebagainya. Permasalahan mengenai pengamanan aset daerah itu emestinya segera diselesaikan. Meskipun belum sempurna tetapi harus ada perbaikan dalam pengamanan sebab aset daerah adalah kekayaan yang seharusnya dipelihara, diamankan, serta dimanfaatkan sebaik mungkin menjadi amanah yang harus diambil untuk masyarakat.

Untuk menjawab tantangan di atas maka lahirlah Peraturan Pemerintah Nomor 27 Tahun 2014 tentang Pengelolaan Barang Milik Negara/Daerah. Hal tersebut merupakan perubahan paradigma baru dalam pengamanan barang milik negara/daerah serta memunculkan optimisme baru dalam penataan dan pengamanan barang/aset negara/daerah yang lebih tertib, akuntabel dan transparan. Pasal 42 ayat (1) menyatakan bahwa "Pengelola barang, pengguna barang dan/kuasa pengguna barang wajib melakukan pengamanan barang milik negara/daerah yang berada dalam penguasaannya". Pasal 42 (2) "Pengamanan Barang Milik Negara/Daerah sebagaimana dimaksud pada ayat (1) meliputi pengamanan administrasi, pengamanan fisik, dan pengamanan hukum". Pasal 43 ayat (1) "Barang Milik Negara/Daerah berupa tanah harus disertipikatkan atas nama Pemerintah Republik Indonesia/Pemerintah Daerah yang bersangkutan". Oleh sebab itu, cakupan manajemen aset negara terdiri atas perencanaan kebutuhan juga penganggaran; pengadaan; pemanfaatan; pemakaian; pengamanan serta perawatan; penilaian; pembersihan; pengalihan; penatausahaan; pengarahan, pengawasan, juga pengelolaan. Proses itu adalah siklus logistik yang lebih terinci yang didasarkan kepada evaluasi pentingnya penyesuaian untuk siklus perbendaharaan dalam kerangka yang lebih luas (finansial negara).

Aset daerah harus dijaga, dikelola, diamankan dan dimanfaatkan dengan sebaik mungkin, selain menjadi amanah yang seharusnya dipertanggungjawabkan kepada masyarakat selaku stakeholder. Aset daerah juga merupakan sumber potensial 
penerimaan daerah serta dapat membantu meningkatkan Pendapatan Asli Daerah (PAD). Oleh karena itu, pemerintah daerah harus pandai dan terampil dalam mengelola aset atau barang milik daerah serta dituntut untuk membenahi sistem pengelolaan aset daerah dengan berpedoman pada regulasi dan Undang-Undang yang berlaku.

Peraturan Pemerintah Nomor 27 Tahun 2014 tentang Pengelolaan Barang Milik Negara/Daerah merupakan acuan utama pemerintah dalam pengelolaan aset daerah, serta dipertegas dengan Peraturan Menteri Dalam Negeri Nomor 19 Tahun 2016 tentang Pedoman Pengelolaan Barang Milik Daerah. Aset daerah ialah suatu potensi ekonomi dan sumber daya yang bersifat mutlak bagi setiap pemerintah daerah. Pengelolaan aset yang baik akan berkontribusi besar bagi pemerintah daerah, sebaliknya jika pengelolaannya buruk maka akan berdampak buruk pula pada pemerintah daerah tersebut.

Aset atau barang milik daerah itu sendiri dikelola oleh unit organisasi yang memiliki hak dan tanggung jawab atas aset tersebut. Pengelola barang/aset daerah tersebut ialah pejabat yang berdaulat serta berkewaijban menetapkan kebijakan dan pedoman serta melakukan pengelolaan barang milik negara/daerah. Pengelolaan aset atau barang milik daerah, pemerintah daerah dituntut agar bisa dengan profesional serta mandiri mengelola asetnya dengan keahlian pengelolaan aset yang terbagi kedalam lima tahapan kinerja, yakni: inventarisasi aset, legal audit, penilaian aset, optimalisasi pemanfaatan aset dan pengawasan dan pengendalian dengan pengembangan Sistem Informasi Manajemen Aset.

Menjumpai permasalahan manajemen aset daerah butuh proses yang begitu panjang, pemerintah daerah dituntut agar bekerja keras dalam mengimplementasikannya supaya tujuan itu dapat teraih. Untuk meraih sesuatu itu pastinya bukan persoalan yang gampang, sebab tidak sedikit hal yang semestinya diperbaharui serta diperbaiki. Prinsip Good Governance, menuntut bahwa Pemerintah Daerah harus membuat laporan keuangan yang transparan dan akuntabel yang mana akan menghasilkan pekerjaan yang baik, begitu pula sebaliknya. Semuanya harus dilihat dari tupoksinya dan harus disesuaikan dengan pejabat yang diperlukan sehingga tidak terjadi pemerintahan yang kaya struktur tapi miskin fungsi, dan tidak juga terjadi sebaliknya kaya fungsi tapi miskin struktur, harus seimbang antara keduanya. Peraturan perundang-undangan tentang pengelolaan aset daerah juga harus dipertegas, sepanjang waktu kebijakan yang ada hanya terkait teknis manajemen serta tidak adanya peraturan perundang-undangan yang mengatur perihal/punishment bagi pemerintah yang lengah Tupoksinya.

Pengelolaan Barang Milik Daerah Kota Semarang diatur dalam Peraturan Daerah Nomor 5 Tahun 2007 perihal Pengelolaan Barang Milik Daerah. Dalam Perda tersebut disebutkan bahwa Walikota ialah pemilik kekuasaan pengelolaan Barang Milik Daerah. Walikota dibantu oleh Sekretaris Daerah selaku pengelola barang, Kepala Bagian Umum/Perlengkapan/Unit pengelola Barang Milik Daerah selaku Pembantu Pengelola Barang, Kepala SKPD selaku Pengguna Barang, Kepala Unit Pelaksana Teknis Daerah sebagai Kuasa Pengguna Barang, Penyimpan Barang dan Pengurus Barang. Di dalam Perda ini juga diatur mengenai tugas inti serta fungsi pejabat 
pengelola barang milik daerah. Para pengurus barang diangkat berdasarkan Keputusan Walikota Semarang Nomor 030/5/2016 tanggal 4 Januari 2016 tentang Penunjukan Pengurus Barang dan Penyimpan Barang terhadap Satuan Kerja Perangkat Daerah/Unit Kerja di Lingkungan Pemerintah Kota Semarang Tahun 2016. Dalam Keputusan Walikota tersebut juga disebutkan tugas dari Pengurus Barang dan Penyimpan Barang.

Penelitian ini lebih mengacu pada penelitian yang dilakukan Rorimpandey dkk (2016) bertujuan untuk menganalisis kesesuaian pengelolaan Barang Milik Daerah Kabupaten Minahasa Selatan dengan Peraturan Pemerintah No. 27 Tahun 2014. Akan tetapi pada penelitian ini yang dilakukan adalah melakukan analisis terhadap Implementasi Kebijakan Pengamanan Aset Tanah Milik Pemerintah Kota Semarang Berdasarkan PP Nomor 27 Tahun 2014.

\section{Metode Penelitian}

Karya ilmiah ini berdasarkan penelitian dengan menggunakan jenis penelitian kualitatif (Sugiyono, 2012). Sumber data yang digunakan, yaitu data primer yang berasal dari wawancara dan observasi dan dokumentasi dan data sekunder diperoleh dari Laporan Hasil Pemeriksaan BPK (Bungin, 2007). Lokasi penelitian dilakukan pada Badan Pengelolaan Keuangan Aset Daerah (BPKAD) Kota Semarang sebagai pengelola Barang Milik Daerah di Pemerintah Kota Semarang dan pemerintah kelurahan di Kota Semarang.

Pemilihan pemberi informasi dalam penelitian ini dilaksanakan dengan cara purposive dengan pertimbangan bahwa informan yang dipilih adalah orang-orang yang benar-benar mengetahui atau terlibat langsung dengan fokus penelitian. Informan pada penelitian ini adalah Kepala Bidang pada Bidang Aset BPKAD Kota Semarang, Staf Bidang Aset (Pengurus Barang) BPKAD Kota Semarang, Kepala Kelurahan Jatibarang Kecamatan Mijen, dan Kepala Kelurahan Kedungpane Kecamatan Mijen. Adapun teknik penelitian ini menggunakan observasi, wawancara dan dokumentasi (Moleong, 2008).

Menurut (Miles \& Huberman, 2007), analisis data kualitatif ada tiga alur aktivitas yang berlangsung bersamaan. Kegiatan dalam analisis data, yaitu: Condensation Data, Display Data, dan Conclusion Drawing/Verifications. Analisis data yang digunakan melalui pendekatan kualitatif, yaitu menjawab dan memecahkan masalah dengan melakukan pemahaman dan pendalaman secara menyeluruh guna menghasilkan data yang akurat dari obyek yang diteliti kemudian dipaparkan sesuai dengan kondisi dan waktu. Analisis data pada penelitian kualitatif, dilaksanakan semenjak sebelum memasuki lapangan, selama di lapangan, serta setelah selesai di lapangan. 


\section{Hasil dan Pembahasan}

\section{A. Implementasi Kebijakan Pengamanan Aset Tanah Milik Pemerintah Kota Semarang}

Menurut (Purwanto, 2015), implementasi intinya ialah aktivitas agar menyalurkan keluaran peraturan (to deliver policy output) yang dilaksanakan oleh para implementer terhadap kelompok sasaran (target group) sebagai upaya agar dapat meraih tujuan kebijakan. Tujuan peraturan diharap agar muncul ketika policy output bisa diterima serta dimanfaatkan dengan baik oleh kelompok sasaran agar dalam jangka panjang hasil kebijakan akan dapat diwujudkan.

Grindel dalam (Akib, 2012)yang menjelaskan bahwa implementasi merupakan proses umum tindakan administratif yang dapat diteliti pada tingkat program tertentu. Model implementasi Kebijakan Jeffrey Pressman dan Aaron Wildavsky dalam (Anggara, 2014) ini menjelaskan tentang model implementasi kebijakan yang paling awal muncul. Implementasi dapat berhasil bergantung terhadap keterikatan diantara beragam organsiasi serta departemen pada tingkat lokal yang berpartisipasi dalam penerapan. Jika ada relasi kolaborasi dalam rangkaian mata rantai itu yang defisit sehingga akan menimbulkan kegagalan penerapan.

Sesuai Standar Operasional Prosedur (SOP) terhadap Pengamanan Barang Milik Daerah, Sekretaris Daerah selaku pengelola barang dengan peran dan tugas penyimpanan bukti kepemilikan bagi barang milik daerah. Dengan demikian, Sekretaris Daerah Kota Semarang sesuai peran dan fungsinya selaku pengelola barang menyimpan segala bukti kepemilikan terhadap aset tanah tersebut. Pengamanan fisik terhadap Barang Milik daerah berupa tanah dilakukan dengan maksud untuk mencegah terjadinya penurunan fungsi tanah, penurunan nilai tanah serta agar semua pihak mengetahui tanah tersebut milik Pemerintah Kota Semarang dan dapat dilakukan antara lain dengan cara pemagaran, pemasangan tanda batas tanah serta pemasangan papan tanda kepemilikan. Pemagaran serta penerapan papan tanda kepemilikan dilaksanakan oleh pemakai bagi tanah dan/atau gedung yang dipakai untuk pengadaan tugas inti sertta fungsi serta tanah dan/atau bangunan yang sudah diberikan dari pengguna pada Kepala Daerah.

Sesuai SOP terhadap Pengamanan Barang Milik Daerah, Sekretaris Daerah selaku pengelola barang dengan peran dan tugas penyimpanan bukti kepemilikan terhadap barang milik daerah. Dengan demikian, Sekretaris Daerah Kota Semarang sesuai peran dan fungsinya selaku pengelola barang menyimpan segala bukti kepemilikan terhadap aset tanah tersebut. Pengamanan hukum mencakup aktivitas melengkapi bukti status kepemilikan tanah, sedangkan upaya hukum dilakukan apabila terjadi pelanggaran hak atau tindak pidana dan/atau perdata. Pengamanan Hukum atas Barang Milik Daerah berupa tanah dilakukan dengan maksud agar aset tanah memiliki kelengkapan berupa surat-menyurat maupun data-data yang sah tentang kepemilikan tanah tersebut. Bukti kepemilikan yang ada harus berkekuatan hukum seperti sertifikat tanah. 
Selanjutnya dijelaskan tentang Mekanisme dan Prosedur Kerja Berdasarkan SOP Pengamanan barang Milik Daerah Pemerintah Kota Semarang yang diuraikan sebagai berikut:

1) OPD melaksanakan pengamanan administratif melalui pencatatan pemasangan label terhadap barang milik daerah, pengamanan fisik dengan pemagaran serta pemasangan papan tanda kepemilikan tanah dan bangunan serta tindakan hukum dengan melakukan musyawarah untuk penyelesaian atas barang milik daerah yang memiliki masalah dengan pihak lain.

2) BPKAD selaku pembantu pengelola barang milik daerah melakukan koordinasi dengan OPD terhadap pelaksanaan pengamanan administratif, pengamanan fisik dan tindakan hukum yang dilaksanakan oleh OPD.

3) Dalam hal jika tidak tercapai penyelesaian atas barang milik daerah yang memiliki masalah dengan pihak lain atau tidak ditemukan kata mufakat, OPD berkoordinasi dengan Bagian Hukum dalam upaya pengadilan perdata atau pidana. Selanjutnya dilakukan penerapan hukum melalui tindakan represif/pengambil alihan, penyegelan, penyitaan secara paksa oleh Satuan Polisi Pamong Praja (SATPOL PP) bersama Bagian Hukum/Pembantu Pengelola.

Pengelolaan aset atau barang milik daerah yang dilakukan BPKAD Kota Semarang sudah dilakukan sesuai prosedur yang ada. Sesuai dengan pengamatan yang dilakukan, bahwa prosedur tersebut menyesuaikan dengan Peraturan Pemerintah Nomor 27 Tahun 2014 tentang Pengelolaan Barang Milik Negara/Daerah dengan tetap menggunakan Peraturan Menteri Dalam Negeri omor 17 Tahun 2007 tentang Pedoman Teknis Pengelolaan barang Milik Daerah sebagai landasan. Selanjutnya diturunkan Peraturan Daerah Kota Semarang Nomor 5 Tahun 2007 tentang Pengelolaan Barang Milik Daerah.

Namun dalam setiap pelaksanaannya, masih saja terdapat berbagai kendala. Hal ini dapat diketahui berdasarkan hasil wawancara dengan Kepala Bidang Aset Daerah BPKAD Kota Semarang yang mengatakan bahwa: "Terdapat aset tanah milik pemerintah Kota Semarang yang belum bersertifikat. Untuk mengadministrasikan tanah-tanah milik pemerintah daerah kendalanya adalah karena tanah yang dikuasai pemerintah itu adalah tanah turun-temurun yang dikuasai oleh pemerintah daerah serta bukti surat-suratnya terdapat yang mudah dicari serta juga yang sulit dicari bukti kepemilikannya.

Jika dilihat dari sejarah kepemilikan aset tanah tersebut salah satunya adalah karena terjadinya otonomi daerah yang mana aset tanah sebelumnya milik pemerintah provinsi, diserahkan kepada pemerintah kabupaten/kota dengan tanpa dilengkapi oleh surat-surat pendukung. Belum lagi timbulnya komplain dari ahli waris yang mengaku akan kepemilikan tanah tersebut. Selain itu ada ketidaksesuaian data tanah dengan sertifikat yang ada sehingga tidak sesuainya keterangan pengadministrasian data yang ada". Di samping itu, tidak semua pengelola Aset/Barang Milik Daerah memahami secara dalam tentang 
Permendagri No. 17 Tahun 2007 tentang Pedoman Teknis Pengelolaan Barang Milik Daerah yang menjadi acuan dalam pengelolaan Aset ataupun Barang Milik Daerah.

Lebih lanjut, hasil dari fenomena yang diamati dan dikaji selama penulis melakukan penelitian pada BPKAD Bidang Aset, yaitu dari total 3.627 persil tanah yang dikuasi oleh pemerintah kota Semarang sampai dengan per 31 Desember 2018, masih terdapat banyak persil tanah yang belum bersertifikat Hak Pakai atas nama Pemerintah Kota Semarang, yaitu sebanyak 1.544 persil tanah $(42,56 \%)$.

Kepemilikan aset tanah masih banyak yang tidak didukung dengan bukti hak atas tanah yang sah (sertifikat) sehingga hak atas aset tersebut tidak jelas dan rawan terhadap penyalahgunaan. Serta di beberapa lokasi dengan aset tanah milik pemerintah diduduki oleh warga dengan secara tidak sah. Administrasi terhadap bukti kepemilikan Aset Daerah masih banyak yang tidak tertib. Terdapat beberapa Barang Milik Daerah berupa aset tanah yang belum diserahkan status penggunaannya oleh Kepala Daerah sebagai Pemegang Kekuasaan Pengelolaan Barang Milik Daerah kepada Pemerintah Kota Semarang.

Penyertifikatan tanah-tanah pemerintah yang berasal dari pemberian atas Pemerintah Pusat maupun Pemerintah Provinsi kepada daerah tidak segampang yang dibayangkan. Berita acara penyerahan umumnya tidak disertai dengan Surat Pelepasan Hak (SPH) sehingga syarat untuk meningkatkan status tanah menjadi tanah bersertifikat belum cukup dengan Berita Acara saja. Selain itu, Pinjam Pakai Tanah kepada Pihak Ketiga masih banyak yang tidak sesuai ketentuan dan tidak mempunyai dasar perjanjian yang jelas. Pemanfaatan tanah milik Pemerintah Daerah belum didukung dengan bukti perjanjian serta hasil/pendapatan sewa tidak/belum diserahkan ke Kas Daerah. Serta adanya Tanah Milik Pemda yang berstatus Bangun Guna Serah belum memiliki Bukti Kepemilikan yang Legalitas dan bangunan di atas tanah tersebut dikuasai oleh pihak lain

Upaya untuk menghadapi permasalahan-permasalahan yang terjadi sudah dilakukan demi terciptanya pengelolaan aset/barang milik daerah dengan baik, khususnya bagi aset tanah yang merupakan salah satu aset penting yang dapat bernilai guna tidak hanya sekarang tapi juga di masa yang akan datang. Bidang Aset Daerah pada BPKAD Kota Semarang telah melaksanakan pengajuan permohonan pembuatan bukti kepemilikan yang sah atau sertifikat untuk aset tanah yang belum bersertifikat atas nama pemerintah Kota Semarang kepada Badan Pertanahan Nasional (BPN), namun dalam prosesnya BPN tidak mengabulkan semua permohonan tersebut karena dinilai data masih kurang lengkap, akan tetapi data yang kurang lengkap tersebut tidak langsung disampaikan kembali oleh BPN kepada pemerintah Kota Semarang sehingga pada saat pengajuan permohonan-permohonan berikutnya menjadi terhambat. 
Mengenai optimalisasi pengamanan dan pemeliharaan aset tanah, diawali dengan cara persuasif kepada pihak ahli waris yang merasa bahwa aset tanah tersebut miliknya, yang padahal aset tanah tersebut adalah milik pemerintah. Pengamanan yang dilakukan dengan tetap melakukan proses persuasif bagi masyarakat yang menggunakan lahan dengan tanpa izin. Untuk proses pengadministrasian sertifikat tetap berkoordinasi kepada Badan Pertanahan Nasional (BPN).

Optimalisasi yang dilakukan oleh BPKAD Kota Semarang dalam proses pengamanan aset tanah dilaksanakan dengan cara :

1) Mengidentifikasi aset-aset pemerintah Kota Semarang yang ada;

2) Pengembangan database aset Pemerintah Kota Semarang dengan memakai aplikasi Sistem Informasi Manajemen Aset (SIMA) dan Sistem Informasi Manajemen Barang Daerah (SIMBADA) yang dibuat untuk mempermudah pendataan aset daerah serta aset tanah.

3) Pengamanan administratif (pencatatan, pemasangan label);

4) Pengamanan fisik (pemagaran, pemasangan papan tanda kepemilikan);

5) Tindakan hukum (musyawarah untuk mencapai penyelesaian, upaya pengendalian perdata, serta pengimplementasian hukum dengan tindakan represif).

\section{B. Faktor Pendukung dan Penghambat Implementasi Kebijakan Pengamanan Aset Tanah Milik Pemerintah Kota Semarang}

Faktor yang pertama, yaitu struktur birokrasi menjadi penting dalam implementasi kebijakan. Aspek struktur birokrasi ini mencakup dua hal penting, yakni proses serta struktur organisasi pelaksana sendiri. Mekanisme implementasi program ditentukan melalui Standar Operating Procedure (SOP) yang dicantumkan dalam guideline program kebijakan. SOP yang baik mencantumkan kerangka kerja yang tersusun, langsung ke hal inti dan mudah dipahami oleh siapapun karena akan menjadi acuan dalam bekerjanya implementor, sedangkan sturktur organisasi pelaksana harus menghindari hal berbelit, panjang dan kompleks. Strutur organisasi pelaksana harus memastikan terdapatnya pemerolehan keputusan atas peristiwa yang tidak biasa dalam program dengan cepat.

Berkaitan dengan struktur organisasi dalam kegiatan Kebijakan Pengamanan Aset Tanah Milik Pemerintah Kota Semarang, diperoleh hasil bahwa SOP meliputi identifikasi, inventarisasi, koordinasi, pengamanan administratif, pengamanan fisik, dan pengamanan hukum. Akan tetapi dalam pelaksanaannya masih banyak permasalahan dan kendala-kendala birokrasi. Kondisi ini menjadi faktor yang menghambat kebijakan pengamanan aset tanah milik Pemkot Semarang. Selain itu koordinasi yang terjadi antar instansi yang terkait sudah berjalan, tetapi masih kurang optimal juga menjadi faktor yang menjadi penghambat.

Faktor yang kedua, yaitu sumber daya, di mana sumber daya menekankan setiap kebijakan harus didukung oleh sumber daya yang memadai, baik sumber daya manusia maupun sumber daya finansial. Sumber daya manusia adalah kecukupan 
baik kualitas dan kuantitas implementor yang dapat melingkupi seluruh kelompok sasaran. Sumber finansial adalah kecukupan modal investasi atas sebuah program/kebijakan. Keduanya harus diperhatikan dalam implementasi kebijakan. Sebab tanpa kehandalan implementor, kebijakan menjadi kurang energik dam berjalan lambat, sedangkan sumber daya finansial menjamin keberlangsungan kebijakan. Tanpa ada dukungan finansial yang memadai, program tidak dapat berjalan efektif dan cepat dalam mencapai tujuan dan sasaran.

Dukungan finansial bersumber dari PAD Kota Semarang yang selalu mengalami peningkatan dari tahun 2016 sampai dengan 2018. Sumber PAD yang selalu mengalami peningkatan dari tahun 2016 sampai dengan tahun 2018 adalah pajak daerah serta hasil pengelolaan kekayaan daerah yang dipisahkan, sedangkan yang fluktuatif adalah sumber PAD dari retribusi daerah dan pos lain-lain yang sah.

Pemerintah Kota Semarang berupaya ke arah kemandirian dalam pembiayaan pembangunan, salah satunya lewat siklus pengelolaan aset tanah sebagai kekayaan daerah. Pemerintah Kota Semarang berupaya melakukan usaha itu dengan berasaskan pada peraturan-peraturan yang berlaku. Bentuk pemanfaatan atas tanah untuk mendukung PAD antara lain dengan sewa dan kerjasama pemanfaatan. Sewa adalah imbalan yang diterima atau diperoleh dengan nama dan dalam bentuk apapun sehubungan dengan penggunaan tanah milik Pemerintah Kota Semarang. Penyewaan merupakan penyerahan hak penggunaan/pemakaian tanah milik Pemerintah Kota Semarang pada pihak ketiga dalam hubungannya dengan sewa menyewa dengan ketentuan pihak ketiga itu mesti memberikan imbalan: uang sewa bulanan, atau tahunan, atau jangka waktu tertentu, baik sekaligus ataupun secara berkala.

Pemanfaatan aset tanah dengan kerjasama pemanfaatan dilakukan dengan tujuan memaksimalkan daya guna serta hasil guna aset tanah milik Pemerintah Kota Semarang dalam rangka meningkatkan pendapatan daerah. Kerjasama pemanfaatan aset tanah dapat dioptimalkan dengan kerjasama pelayanan misalnya perawatan jaringan, pungutan uang parkir kendaraan, penagihan rekening dan lain-lain. Kerjasama keuntungan merupakan bentuk kerjasama di mana keuntungan dibagi berdasarkan perjanjian yang sudah disepakati sebelumnya. Kerjasama produksi merupakan bentuk kerjasama dengan mitra kerja yang telah memberikan wewenang untuk memproduksi suatu produk dengan menggunakan aset tanah milik Pemerintah Kota Semarang, misalnya kerjasama industri aset daerah, pengelolaan tanah sawah/tanah kering miliki daerah, dan lain-lain. Melainkan, sebagian persoalan timbul mencakup: status kepemilikan aktual tanah serta legalitas status kepemilikannya, juga minimnya partisipasi pendapatan dari sektor ini ke pendapatan asli daerah.

Hasil penelitian menunjukkan bahwa bahwa keahlian sumber daya manusia yang dimiliki oleh pihak-pihak yang terkait masih kurang optimal, anggaran yang tersedia tercukupi dan terbatas untuk tingkat BPKAD saja, dan untuk anggara di tingkat kelurahan tidak ada. Mengenai ketersediaan fasilitas untuk mendukung pelaksanaan kebijakan belum sepenuhnya memadai. Kewenangan yang diberikan 
pada ASN dalam melaksanakan Kebijakan Pengamanan Aset Tanah Milik Pemerintah Kota Semarang dirasa masih kurang efektif dibandingkan dengan aset tanah dimiliki. Kondisi seperti ini juga menjadi faktor yang menghambat Kebijakan Pengamanan Aset Tanah Milik Pemerintah Kota Semarang.

Faktor ketiga, yaitu disposisi yang menekankan terhadap karakteristik yang erat kepada implementor kebijakan/program. Karakter yang begitu penting dimiliki implementor yaitu kejujuran, komitmen serta demokratis. Implementor yang mempunyai komitmen yang tinggi serta jujur hendak selalu bertahan di antara hambatan yang ditemui dalam kebijakan. Kejujuran memusatkan implementor untuk selalu ada dalam arah program yang sudah digariskan dalam guideline program/kebijakan. Komitmen dan kejujuran membawanya semakin antusias dalam melakukan tahap-tahap program dengan konsisten. Sikap yang demokratis akan meningkatkan kesan baik implementor dan kebijakan dihadapan anggota kelompok sasaran. Sikap ini akan menurunkan resistensi dari masyarakat dan menumbuhkan rasa percaya dan kepedulian kelompok sasaran terhadap implementor dan program/kebijakan.

Berkaitan dengan disposisi dalam kegiatan Kebijakan Pengamanan Aset Tanah Milik Pemerintah Kota Semarang, diperoleh hasil bahwa aset tanah milik Pemerintah Kota Semarang harus dapat dijaga / diamankan sesuai dengan regulasi yang telah diatur baik secara administrasi, fisik, hukum dan perlu dilakukan pengawasan secara terus menerus. Dalam hal ini dari pihak Bidang Aset BPKAD memberikan insentif sebagai pelaksana pengamanan Aset Tanah Milik Pemerintah Kota Semarang. Hal ini menjadi faktor pendukung dalam pelaksanaan Kebijakan Pengamanan Aset Tanah Milik Pemerintah Kota Semaran, sedangkan berkaitan dengan kegiatan tentang kebijakan ini diketahui bahwa kelurahan tidak menerima insentif atau honor dari Pemkot Semarang. Kondisi ini dapat menjadi penghambat pelaksanaan Kebijakan Pengamanan Aset Tanah Milik Pemerintah Kota Semarang.

Faktor yang keempat, yaitu komunikasi yang menekankan bahwa setiap kebijakan akan dapat dilaksanakan dengan baik jika terjadi komunikasi efektif antara pelaksana program (kebijakan) dengan para kelompok sasaran (target grup). Tujuan dan sasaran dari program kebijakan dapat disosialisasikan secara baik sehingga dapat menghindari adanya distorsi atas kebijakan dan program. Berkaitan dengan komunikasi dalam kegiatan Kebijakan Pengamanan Aset Tanah Milik Pemerintah Kota Semarang, diperoleh hasil bahwa adanya komunikasi dan koordinasi yang cukup baik dengan pihak-pihak terkait dengan berhubungan dengan pengamanan Aset Tanah Milik Pemerintah Kota Semarang. Selain itu juga mengajak masyarakat untuk peran serta dalam mengamankan secara fisik aset tanah Milik Pemerintah Kota Semarang sesuai ketentuan yang berlaku. Kondisi ini menjadikan komunikasi menjadi salah satu faktor yang dapat menjadi pendukung pelaksanaan Kebijakan Pengamanan Aset Tanah Milik Pemerintah Kota Semarang. 


\section{Kesimpulan}

Berdasarkan hasil penelitian tentang Implementasi Kebijakan Pengamanan Aset Tanah Milik Pemerintah Kota Semarang Berdasarkan PP Nomor 27 Tahun 2014 maka berdasarkan pembahasan pada bab sebelumnya dapat disimpulkan sebagai berikut :

1. Permasalahan yang dihadapi dalam proses pengamanan aset tanah, yaitu:

a) Tidak semua pengelola Aset/Barang Milik Daerah memahami secara mendalam Permendagri No. 17 Tahun 2007 tentang Pedoman Teknis Pengelolaan Barang Milik Daerah yang menjadi acuan dalam pengelolaan Aset ataupun Barang Milik Daerah;

b) Kepemilikan aset tanah masih banyak yang tidak didukung dengan bukti hak atas tanah yang sah;

c) Administrasi terhadap bukti kepemilikan Aset Daerah masih banyak yang tidak tertib;

2. Proses pengamanan pada aset tanah dilakukan dengan cara :

a) Mengidentifikasi aset-aset pemerintah Kota Semarang yang ada;

b) Pengembangan database aset Pemerintah Kota Semarang dengan menggunakan aplikasi Sistem Informasi Manajemen Aset (SIMA) dan Sistem Informasi Manajemen Barang Daerah (SIMBADA) yang dibuat untuk mempermudah pendataan aset daerah serta aset tanah.

c) Pengamanan administratif (pencatatan, pemasangan label);

d) Pengamanan fisik (pemagaran, pemasangan papan tanda kepemilikan);

e) Tindakan hukum (musyawarah untuk mencapai penyelesaian, upaya pengendalian perdata, serta pengimplementasian hukum dengan perilaku represif).

3. Faktor yang menghambat kebijakan pengamanan aset tanah milik Pemkot Semarang, antara lain :

a) Sistem birokrasi yang masih kurang efisien dan masih lemahnya koordinasi yang terjadi diantara instansi yang terhubung.

b) Keahlian sumberdaya manusia yang dimiliki oleh pihak-pihak yang terkait masih kurang optimal.

c) Ketersediaan fasilitas untuk mendukung pelaksanaan kebijakan belum sepenuhnya memadai.

d) Kewenangan yang diberikan pada ASN dalam melaksanakan Kebijakan Pengamanan Aset Tanah Milik Pemerintah Kota Semarang masih kurang efektif.

4. Faktor yang mendukung kebijakan pengamanan aset tanah milik Pemkot Semarang, antara lain :

a) Adanya insentif sebagai pelaksana pengamanan Aset Tanah Milik Pemerintah Kota Semarang

b) Adanya komunikasi serta koordinasi yang cukup baik dengan pihak-pihak terkait dengan berhubungan dengan pengamanan Aset Tanah Milik Pemerintah Kota Semarang. 
Implementasi Kebijakan Pengamanan Aset Tanah Milik Pemerintah Kota Semarang

c) Mengajak masyarakat untuk partisipasi dalam mengamankan secara fisik aset tanah Milik Pemerintah Kota Semarang. 
Rudy Kurniawan

\section{BIBLIOGRAFI}

Akib, Haedar. (2012). Implementasi kebijakan: Apa, mengapa dan bagaimana. Jurnal Ilmiah Ilmu Administrasi Publik, 1(1), 1-11.

Anggara, Sahya. (2014). Kebijakan Publik, Bandung. Penerbit CV Pustaka Setia.

Bungin, Burhan. (2007). Analisis data penelitian kualitatif. PT RajaGrafindo Persada.

Miles, Matthew B., \& Huberman, A. Micheael. (2007). Analisis data Kualitatif (Tjetjep Rohedi, Pentj). Jakarta: UI Press.

Moleong, Lexy J. (2008). Metodologi Penelitian Kualitatif eds. Revisi. Bandung: PT Remaja Rosdakarya Offset.

Purwanto, A. E. (2015). Implementasi Kebijakan Publik Konsep dan Aplikasinya di Indonesia. Yogyakarta: Gaya Media.

Saridawati, Saridawati. (2018). Pengelolaan Dan Pengembangan Sumber Daya Manusia Pada Pt. Atmoni Shamasta Prezki. Syntax Literate; Jurnal Ilmiah Indonesia, 3(9), $107-122$

Sugiyono. (2012). Memahami Penelitian Kualitatif. Bandung: CV. Alfabeta. 